\title{
Cryopreservation of Ovarian Tissue: Detailed Description of Methods for Transport, Freezing and Thawing
}

\author{
Kryokonservierung von Ovarialgewebe: detaillierte Beschreibung \\ eines Verfahrens zum Transport, zum Einfrieren und zum Auftauen
}

Authors

Affiliations
V. Isachenko ${ }^{1}$, R. Dittrich ${ }^{2}$, G. Keck ${ }^{3}$, E. Isachenko ${ }^{1}$, G. Rahimi ${ }^{1}$, H. van der Ven ${ }^{4}$, M. Montag ${ }^{5}$, I. Hoffmann², A. Müller ${ }^{2}$, W. Distler ${ }^{3}$, M. W. Beckmann², P. Mallmann ${ }^{1}$

The affiliations are listed at the end of the article

Key words
ovary
o birth
reproductive medicine
Schlüsselwörter
Ovar
- Geburt
- Reproduktionsmedizin

received 24.2.2012

revised $\quad 31.7 .2012$

accepted $\quad 7.8 .2012$

Bibliography

DOI http://dx.doi.org/

10.1055/s-0032-1327812

Geburtsh Frauenheilk 2012; 72:

927-932 @ Georg Thieme

Verlag KG Stuttgart · New York .

ISSN 0016-5751

Correspondence

Dr. Vladimir Isachenko

Universitätsfrauenklinik Köln

Prittwitzstraße 43

$89075 \mathrm{Ulm}$

v.isachenko@yahoo.com

\section{Abstract}

$\nabla$

Purpose: In many cases cancer therapy leads to an irreversible reduction or even loss of ovarian reserve. Cryopreservation of ovarian tissue with subsequent thawing and re-transplantation of tissue after the cancer is in remission constitutes a promising method to preserve fertility in women. To date, more than 25 cases of live births after re-transplantation of cryopreserved ovarian tissue have been published worldwide. In Germany the first live birth after re-transplantation of cryopreserved tissue was in 2011.

Material and Methods: After surgical removal of ovarian tissue in the Gynaecological Clinic of Dresden University, the tissue was sent to the Gynaecological Clinic of Bonn University in a special transport container at $5{ }^{\circ} \mathrm{C}$ and was frozen the next day using $1.5 \mathrm{M}$ dimethyl sulfoxide cryosolution. In 2010 this ovarian tissue was thawed using a sucrose solution in the Gynaecological Clinic of Erlangen University Clinical Centre and was laparoscopically re-transplanted into the patient.

Results: The patient became pregnant, the pregnancy was uneventful, and she gave birth to a healthy boy.

Conclusion: Freezing of ovarian tissue with subsequent re-transplantation as described here is a viable method to preserve fertility in cancer patients.

\section{Introduction \\ $\nabla$}

Oncological treatment is becoming increasingly effective and cancer patients often have a good long-term prognosis, allowing them to lead normal lives. This includes fulfilling their desire to

\section{Zusammenfassung \\ $\nabla$}

Fragestellung: Die Krebstherapie führt häufig zu einer irreversiblen Reduktion oder sogar zum Verlust der ovariellen Reserve. Eine vielversprechende Methode zur Bewahrung der Fertilität bei Frauen ist die Kryokonservierung von Ovarialgewebe mit anschließendem Auftauen und Retransplantation des Gewebes nach überstandener Krebserkrankung. Bis heute wurden weltweit mehr als 25 Geburten nach einer Retransplantation von kryokonserviertem Ovarialgewebegewebe publiziert. In Deutschland kam es 2011 zur ersten Geburt nach Transplantation von kryokonserviertem Gewebe.

Material und Methodik: Nach der Entnahme des Ovarialgewebes an der Frauenklinik der Universität Dresden wurde dieses Gewebe im speziellen Transport-Container bei $5^{\circ} \mathrm{C}$ an die Frauenklinik der Universität Bonn geschickt und am nächsten Tag in einer 1,5-M-Dimethylsulfoxidlösung eingefroren. Im Jahr 2010 wurde in der Frauenklinik des Universitätsklinikums Erlangen dieses Ovarialgewebe aufgetaut und nach Ausverdünnung des Gefrierschutzmittels der Patientin laparoskopisch retransplantiert.

Ergebnisse: Es kam zu einer Schwangerschaft, die vollkommen unauffällig verlief und zur Geburt eines gesunden Jungen in der Universitätsfrauenklinik in Dresden.

Schlussfolgerung: Das Einfrieren des Ovarialgewebes nach der hier vorgestellten Methode ist geeignet, um die Fruchtbarkeit bei Krebspatienten zu bewahren.

have children [1]. As chemotherapy - depending on the therapy regime - can be gonadotoxic, a possible irreversible decrease or complete loss of ovarian reserve may result. Cryopreservation of ovarian tissue with subsequent orthotopic retransplantation after recurrence-free remission 

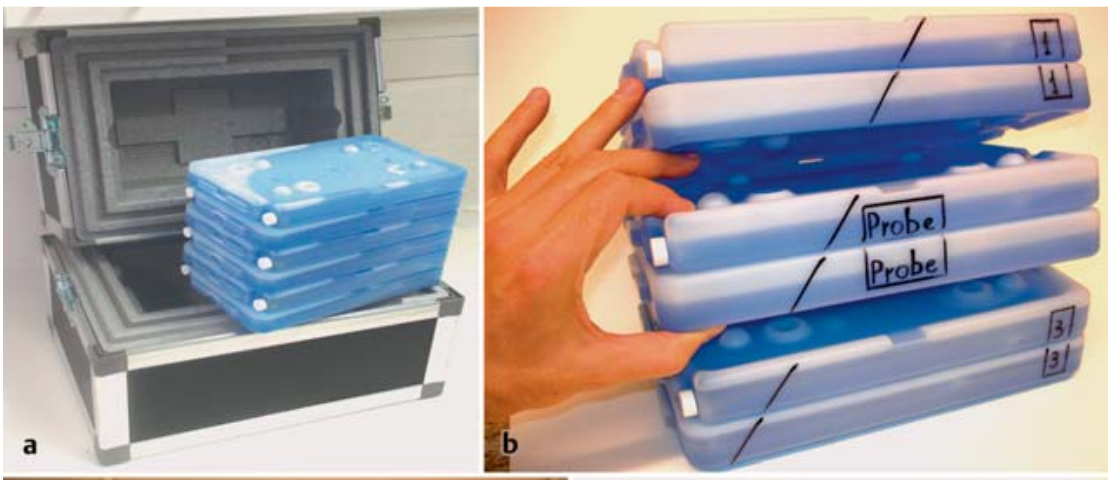

Fig. 1 a to $\mathbf{d}$ Transport-set for ovarian tissue. a Complete transport-set with cooling elements. b Three elements: cooling elements 1 and 3 with the middle element containing the samples. c Middle cooling element for samples, cooled to $4^{\circ} \mathrm{C}$, with transport medium. d External cooling elements 1 and 3, cooled to $-20^{\circ} \mathrm{C}$.

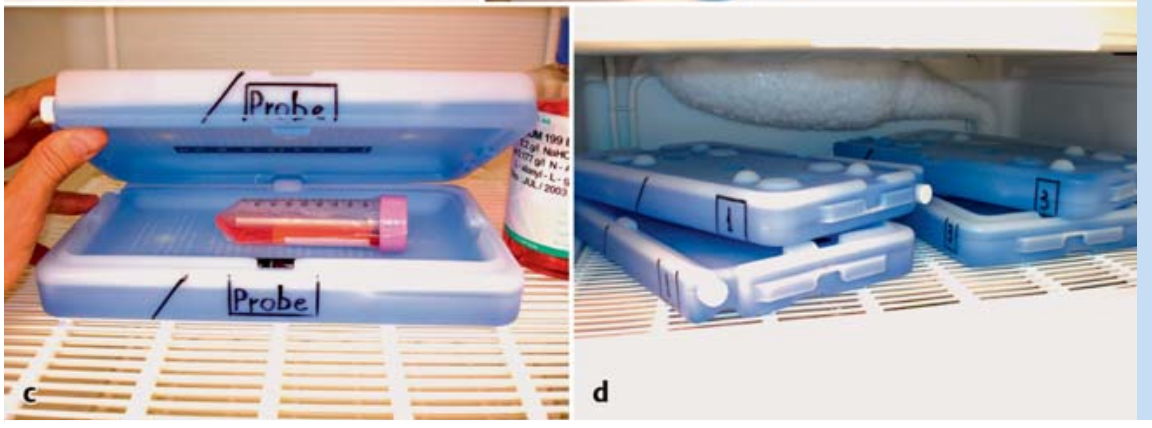

is a promising method to preserve fertility in affected women [2, 3]. To date, more than 25 cases have been published worldwide reporting on live births after orthotopic re-transplantation of cryopreserved ovarian tissue. In Germany the first live birth after re-transplantation of cryo-preserved ovarian tissue occurred in 2011 [4].

A 25-year-old patient developed a Hodgkin lymphoma in 2003. As the patient was from Dresden, she underwent laparoscopic removal of ovarian tissue in the Gynaecological Clinic of Dresden University Hospital to preserve her fertility. Cryopreservation was done in Bonn, as cryopreservation of ovarian tissue is not done routinely in Dresden. For this, the tissue was transported in a suitable transport container to the Gynaecological Clinic of Bonn University Hospital where it was cryopreserved and the tissue samples were stored.

Re-transplantation was done in Erlangen in view of the acknowledged expertise of the Gynaecological Clinic of Erlangen University Hospital in thawing and re-transplanting ovarian tissue. After 5 years with no recurrence of cancer and in view of the patient's continued wish to have a child, the thawed ovarian tissue was re-transplanted in the Gynaecological Clinic of Erlangen University Hospital in 2010, with laparoscopic re-transplantation of the tissue into a peritoneal pocket of the ovarian fossa in the right pelvic wall. Three months after re-transplantation the patient reported her first spontaneous menstrual bleeding, and low-dose stimulation therapy with follicle-stimulating hormone (FSH) was started. After confirmation of a dominant follicle in the transplant area, ovulation was induced with human chorionic gonadotropin (hCG), and timed intercourse was recommended. A pregnancy ensued. The pregnancy was completely uneventful, and a normal boy was delivered in the Gynaecological University Clinic in Dresden on October 10, 2011 [4].

We describe here in detail the method of tissue transportation from Dresden to Bonn, the preparation and cryopreservation of the ovarian tissue together with the method used for thawing and re-transplantation.

\section{Transport and Preparation of Ovarian Tissue for Freezing \\ $\nabla$}

Except where otherwise stated, all chemicals were obtained from Sigma (Sigma Chemical Co., St. Louis, MO, USA). Laparoscopic extraction of ovarian tissue for cryopreservation was done on August 22, 2005 in the Gynaecological Clinic of Dresden University Hospital. After extraction, the tissue was sent to the Gynaecological Clinic of Bonn University Hospital, a member of the FertiPROTEKT network. Within 22 hours, the extracted ovarian tissue fragments were sent from Dresden to Bonn in a Brahma I solution (Cryo BioSystem, Paris, France) in a special transport flask for blood products ( Fig. 1) cooled to $4^{\circ} \mathrm{C}$ for the transportation of ovarian tissue. The company Cryo Bio System no longer produces the Brahma I solution. We now use a solution produced by the Gynaecological Clinic of Cologne University Hospital consisting of Leibovitz's L-15 medium with 5\% SSS (Serum Substitute Supplement, Irvine Scientific, Santa Ana, CA, USA) as an alternative to the Brahma I solution for the transport and preparation of ovarian tissue. The next day, at the Gynaecological Clinic of Bonn University Hospital the ovarian tissue fragments were transferred to a Brahma II medium (CryoBioSystem, Paris, France) ( Fig. $2 \mathrm{a}$ ) and the cortex was partially separated from the stroma using tweezers and a no. 22 scalpel ( $\bullet$ Fig. 2 b). The Brahma II medium is currently also no longer produced by Cryo Bio System. Instead of the Brahma II solution, clinics can make up their own solution, e.g. using Leibovitz's L-15 medium with 5\% SSS. The ovarian tissue fragments were divided into 5-8 strips with a length each of $2-3 \times 1.0-1.2 \mathrm{~mm}$ ( Fig. 1 c) and transferred to $2 \mathrm{ml}$ cryo tubes (Nunc, Roskilde, Denmark) ( $\bullet$ Fig. $1 \mathrm{~d}$ ) for freezing. 


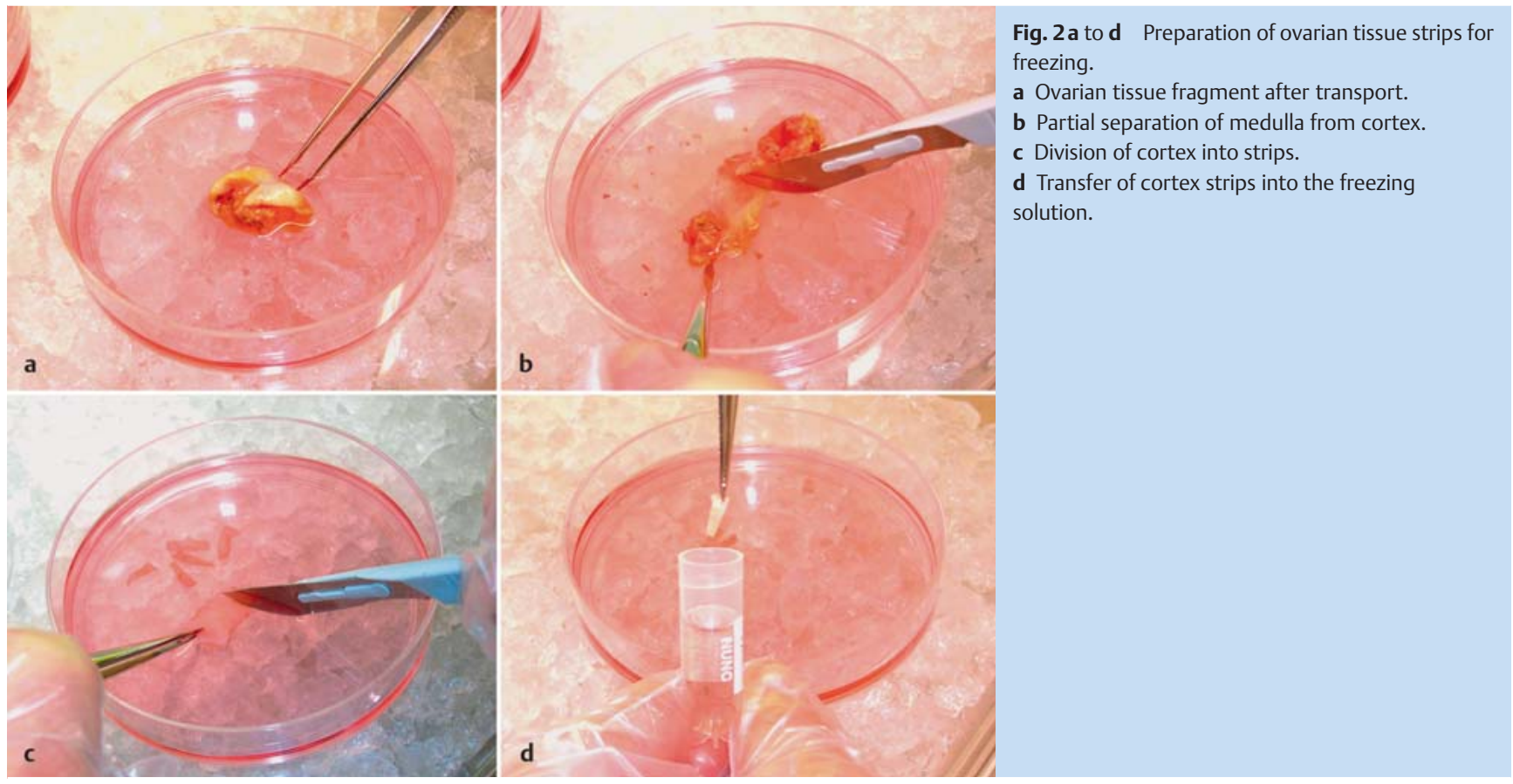

\section{Freezing of Ovarian Tissue \\ $\nabla$}

To freeze the ovarian tissue, $2 \mathrm{ml}$ standard cryo tubes (Nunc, Roskilde, Denmark) were filled with $1.8 \mathrm{ml}$ freezing solution, consisting of L-15 medium (Leibovitz) with L-glutamine + 1.5 M (11.7\%) DMSO $+10 \%$ SSS. The ovarian strips of tissue were transferred to the cryo tubes, placed in ice water for $30 \mathrm{~min}$ ( Fig. 3 a) and subsequently frozen using the IceCube 14 S freezer (SyLab, Neupurkersdorf, Austria) ( Fig.3b). The freezing protocol was as follows: (1) starting temperature $4{ }^{\circ} \mathrm{C}$; (2) cooling from 4 to $-6^{\circ} \mathrm{C}$ at a speed of $-1{ }^{\circ} \mathrm{C} / \mathrm{min}$; (3) auto-seeding at $-6^{\circ} \mathrm{C}$; (4) cooling from -6 to $-34^{\circ} \mathrm{C}$ at a speed of $-0.3^{\circ} \mathrm{C} / \mathrm{min}$, and finally, immersion of the cryo tubes in liquid nitrogen ( $\bullet$ Fig. $3 \mathrm{c}$ ). The tubes were then transferred to the cryobank and stored ( $\bullet$ Fig. $\mathbf{3 d}$ ).

\section{Thawing of Ovarian Tissue \\ $\nabla$}

Thawing of the ovarian tissue was done at the Gynaecological Clinic of Erlangen University Hospital. The cryo tubes with the fragments of ovarian tissue were left at room temperature for $30 \mathrm{~s}$ and subsequently placed in $37^{\circ} \mathrm{C}$ warm water for $1 \mathrm{~min}$ until the ice had completely melted. After defrosting, the pieces of ovarian tissue were removed from the cryo tubes and placed in $5 \mathrm{ml}$ thawing solution (0.75 M sucrose solution in PBS with $10 \%$ human albumin solution [ $5 \% \mathrm{HAS}$ ]) for $15 \mathrm{~min}$ at room temperature. The tissue fragments were then placed in $0.5 \mathrm{M}$ sucrose solution for $15 \mathrm{~min}$, then in $0.25 \mathrm{M}$ sucrose solution for $15 \mathrm{~min}$, and finally transferred to a PBS solution (with 10\% HAS). Directly afterwards, the tissue was transplanted using the technique previously described [5].
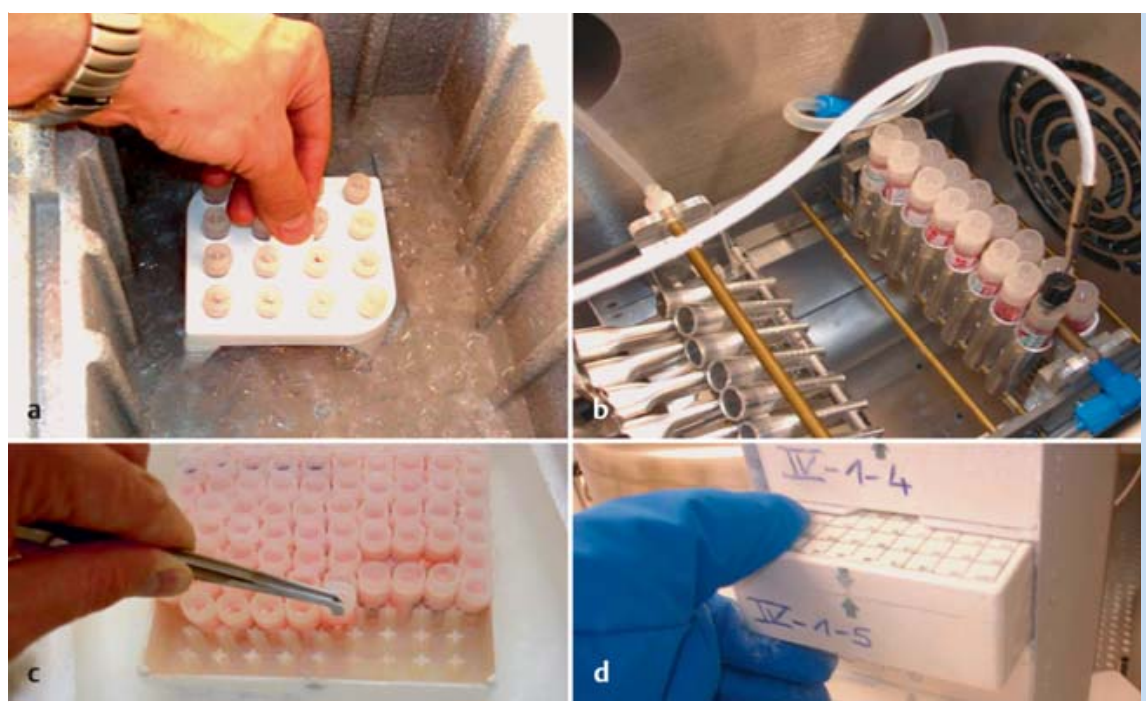

Fig. 3 a to d Cryopreservation of ovarian tissue. a Cooling of cryo tubes in ice water to $4^{\circ} \mathrm{C}$. b Freezing of cryo tubes: auto-seeding block. c Immersion of cryo tubes in liquid nitrogen after cooling down to $-34^{\circ} \mathrm{C}$. d Storage of cryo tubes. 


\section{Discussion}

$\nabla$

A number of different procedures are successfully used worldwide for the cryopreservation of ovarian tissue. Births have only ensued when slow freezing procedures were used. Cryoprotectants include ethylene glycol, propylene glycol and DMSO. The procedure described here used only DMSO as cryoprotectant and resulted in the birth of the first child to be born in Germany after re-transplantation of cryopreserved ovarian tissue. The procedure described is also suitable for freezing ovarian tissue. The Gynaecological Clinic of Cologne University Hospital currently uses a modified freezing protocol, in which ethylene glycol is used for cryoprotection in addition to DMSO [5-10]. The new freezing solution consists of L-15 medium (Leibovitz) with L-glutamine $+6 \%$ DMSO $+6 \%$ ethylene glycol +0.15 M sucrose $+10 \%$ SSS (serum substitute supplement).

In cryopreservation, the time-point at which crystal formation is initiated during the freezing process is particularly important, because if crystal formation is not initiated, so-called spontaneous crystal formation will occur at around $-18^{\circ} \mathrm{C}$. This generates exothermic crystallisation heat, which has an indirectly injurious effect on biological structures. Up until the moment of seeding, the rapidity of the freezing process is not critical. After seeding, the cooling speed must not exceed $-0.3^{\circ} \mathrm{C} / \mathrm{min}$.

In January 2005, an auto-seeding block was designed and produced at the Gynaecological University Clinic in Bonn. The prototype of this block is shown in 0 Fig. $\mathbf{3 b}$ b. The ovarian tissue obtained in the case described here was frozen, and seeding was done using this prototype. The basic principle of the auto-seeding block is as follows. To initiate seeding, liquid nitrogen is conveyed through a metal tube at a certain time-point during the freezing process (at $-6{ }^{\circ} \mathrm{C}$ in our protocol). Seeding is initiated by thermal transfer created by the mechanical contact of the cryo tube with the nitrogen-filled metal tube. The special feature of this autoseeding block is that contact between the cryo tube and the seeding tube occurs passively, without any oscillation, only through gravitational force. The cryo tube with the cryo solution is pressed against the seeding tube by its own weight.

The Cologne Study Group recommends the following alternative thawing protocol with continuous addition of a thawing medium. The cryo tube is first left to stand at room temperature for $30 \mathrm{~s}$ and then immersed for a period of 60 to $75 \mathrm{~s}$ in a water bath with boiling water $\left(100^{\circ} \mathrm{C}\right)$. The precise immersion time of the cryo tube in boiling water is controlled visually by monitoring the ice: the cryo tube is removed from the water bath as soon as the ice at the tip is thinner than $\sim 1 \mathrm{~mm}$. The final temperature of the freezing solution after removal of the cryo tube from the $100^{\circ} \mathrm{C}$ water bath should be between 4 and $10^{\circ} \mathrm{C}$.

If thawing is done in boiling water, there is always a risk of overheating the ovarian tissue fragments. To prevent this we recommend the following. First a compact sponge (Telaprep No. 1, Paul Hartmann AG, Heidenheim, Germany) is placed at the bottom of the $5 \mathrm{ml}$ cryo tube. The ovarian tissue fragment is then placed on the sponge. This prevents the tissue from coming into direct contact with the walls of the $5 \mathrm{ml}$ cryo tube and ensures rapid but "delicate" warming of the ovarian tissue fragments.

After initial thawing, the strips of ovarian tissue are transferred within $5-7$ s to a $100 \mathrm{ml}$ sample container (Sarstedt, Nümbrecht, Germany) with $10 \mathrm{ml}$ solution ( $0.5 \mathrm{M}$ sucrose $+10 \% \mathrm{SSS}+\mathrm{L}-15$ medium) to remove the cryoprotectants.

Removal of cryoprotectants is carried out following the same principles used for ethylene glycol saturation (cf. Figure 1 in Isa- chenko et al., 2006 [7]). The container is constantly agitated by a shaker (200 osc/min at room temperature for $15 \mathrm{~min}$ ). Multiple stage rehydration of the strips of ovarian tissue is done at room temperature for $30 \mathrm{~min}$. Drop rehydration is done using $50 \mathrm{ml}$ culture medium ( $\mathrm{L}-15$ medium $+10 \%$ SSS) in $50 \mathrm{ml}$ tubes (Greiner Bio-One GmbH, Frickenhausen, Germany). The method requires the slow addition (drop by drop) of a culture medium to the sucrose solution. The final sucrose concentration is $0.083 \mathrm{M}$, which practically corresponds to cellular isotonic concentrations. The strips of ovarian tissue are subsequently washed for $10 \mathrm{~min}$ in culture medium.

It is important to maintain constantly low temperatures during transportation and preparation of the strips of ovarian tissue to preserve tissue vitality ( $\bullet$ Fig. 1 and 2 ). Below, we briefly describe the results of our own tests, carried out in the Gynaecological Clinic of Cologne University. The overall aim of these studies was to investigate the effect of low positive temperatures on the viability of human ovarian tissue and to prove or refute any benefit arising from the use of low positive temperatures. The impact of 24-hour cooling of ovarian tissue to a temperature of $5{ }^{\circ} \mathrm{C}$ directly prior to freezing was investigated. Intensity of neo-vascularisation and follicle development served as markers for quality control and were recorded and assessed.

The neutral and positive effects of cooling on tissue have been previously described and discussed. It was shown that the adaptation of warm-blooded animals (rats) to cold is accompanied by mitotic stimulation.

Analysis of hypothalamic tissue function showed that cold temperatures resulted in a twofold increase in thyrotrophin-releasing hormone mRNA synthesis [11]. Moreover a good survival of trophoblastic fragments subjected to $48 \mathrm{~h}$ cooling at $4{ }^{\circ} \mathrm{C}$ was shown. The survival rate did not differ from that of untreated controls (98 and 98\%, respectively) [12].

Previous studies have shown that storage of human ovarian tissue for up to $26 \mathrm{~h}$ at low positive temperatures has no inhibitory effect on follicle development during later in vitro culture. Compared to untreated controls the number of primordial follicles was significantly decreased in all treatment groups due to developments in advanced stages [13].

Wood et al. [14] investigated the impact of storing domestic cat ovaries for a longer period under hypothermic conditions (at $4{ }^{\circ} \mathrm{C}$ for $48 \mathrm{~h}$ ) on follicle atresia and recorded a positive impact. The data, described below, support their results.

In contrast, the study by Yin et al. [15] reported that hypothermic storage of rat ovaries at $4{ }^{\circ} \mathrm{C}$ for $24 \mathrm{~h}$ did not have an atretic effect on ovarian function. Although the ovaries had fewer follicles, this is contrary to the results of the Cologne Study Group. We would explain this phenomenon as species-specific.

The most important factor for the successful transplantation of ovarian tissue is ensuring sufficient blood supply within a very short time. This is decisive for follicular survival [16].

Given that neo-vascularisation is important for nidation and the development of ovarian tissue, the Cologne Study Group uses neo-vascularisation as the criterion for tissue viability and has verified this criterion. The formation of new vessels from already existing vessels is vitally important for many physiological processes. Dysregulation of vascularisation contributes to many diseases, from ischemia to cancer [17].

In fact, neo-vascularisation starts with the formation of very small vessels. The Cologne Study Group used desmin as a marker to demonstrate the formation of these vessels. In our experi- 
ments pieces of human ovarian tissue were divided into the following groups:

- Group 1: pieces cultivated immediately after operation,

- Group 2: pieces cooled to $5^{\circ} \mathrm{C}$ for $24 \mathrm{~h}$ after operation and then cultivated,

- Group 3: pieces frozen immediately after operation, then thawed and cultivated,

- Group 4: pieces cooled to $5^{\circ} \mathrm{C}$ for $24 \mathrm{~h}$ after operation, then frozen, thawed and cultivated.

Ovarian tissue fragments were cultivated for 5 days on chorioallantoic membrane (CAM). The impact of cooling on follicles and the intensity of neo-vascularisation was recorded and assessed based on the detection of desmin expression. Increased neo-vascularisation in the presence of desmin expression was demonstrated. The intensity of immunoreactivity was recorded semi-quantitatively [18]: no immunoreactivity (-), weak immunoreactivity $(+)$, moderate immunoreactivity $(++)$, strong immunoreactivity $(+++)$.

Histological investigation after 5-day CAM culture of pieces of ovarian tissue showed that the primordial, primary and secondary follicles remained viable.

Normal follicle proportions (92, 93, 89 and $90 \%)$ were recorded for groups $1,2,3$ und 4 , respectively ( $p>0.1$ ).

Immunoreactivity for desmin was only seen in the medullary part of the tissue fragments. Groups had the following immunoreactivity:

- Group 1 (pieces cultivated immediately after operation): weak $(+)$,

- Group 2 (pieces cooled to $5^{\circ} \mathrm{C}$ for $24 \mathrm{~h}$ after operation): strong $(+++)$,

- Group 3 (pieces frozen, then thawed after operation): none (-),

- Group 4 (pieces cooled to $5^{\circ} \mathrm{C}$ for $24 \mathrm{~h}$ after operation, then thawed): moderate (++).

The results of other experiments described elsewhere showed that 24-hour cooling to $5^{\circ} \mathrm{C}$ prior to cryopreservation has a positive effect on human ovarian tissue [19].

Our article also contains data previously published elsewhere [4, 20]. In their study, Müller et al. described various aspects of the procedure used for cryobanking of ovarian tissue [4]. The publication also describes the first birth in Germany after the re-transplantation of cryopreserved ovarian tissue [4].

It was noted that oncologists should inform their young female patients with tumour disease scheduled to undergo radio- or chemotherapy more about the different possibilities of preserving fertility and offer more counselling on fertility preservation to these patients.

Dittrich et al. [20] reported on the biological part of the cryobanking process, describing the successful cryopreservation of ovarian tissue after lengthy transportation under hypothermic conditions. Moreover, they proposed taking the possibilities to preserve fertility into consideration when planning oncological treatments and offering patients counselling on fertility preservation by a member of the FertiPROTEKT network (www. fertiprotekt.de).

More than 25 births worldwide have been recorded after retransplantation of cryopreserved ovarian tissue [21].

The aim of our paper was to describe the protocol for ovarian tissue cryopreservation. The focus was on providing detailed information which can be used directly for laboratory protocols. The birth of a child has confirmed the reliability of our protocol. How- ever, we have not confined ourselves to describing technologies from 2005 but instead present more recent versions of these technologies. The practical application of the results of our experiments into the cooling of human ovarian tissue is described. Nowadays, the Gynaecological Clinic of Cologne University Hospital carries out cooling of human ovarian tissue for $22-23 \mathrm{~h}$ prior to cryopreservation as part of its standard protocol.

The reader is thus given the opportunity to decide for himself whether he wishes to utilise the technology used in 2005 or whether he prefers to opt for the technology developed over the last 6 years $[2,3,6,7,19]$.

\section{Conflict of Interest \\ $\nabla$}

None.

\author{
Affiliations \\ ${ }^{1}$ Universitätsfrauenklinik Köln, Cologne \\ 2 Frauenklinik des Universitätsklinikums Erlangen, Erlangen \\ ${ }^{3}$ Universitätsfrauenklinik Dresden, Dresden \\ ${ }^{4}$ Universitätsfrauenklinik Bonn, Bonn \\ ${ }^{5}$ Universitätsfrauenklinik Heidelberg, Heidelberg
}

\section{References}

1 Krebs in Deutschland 2005/2006. Häufigkeiten und Trends. Eine gemeinsame Veröffentlichung des Robert Koch-Instituts und der Gesellschaft der epidemiologischen Krebsregister in Deutschland e.V. 2010: $120 \mathrm{P}$

2 Dittrich R, Maltaris T, Hoffmann I et al. Fertility preservation in cancer patients. Minerva Ginecol 2010; 62: 63-80

3 von Wolff M, Montag M, Dittrich R et al. Fertilitätsprotektion bei Frauen. Empfehlungen des Netzwerks FertiPROTEKT. Geburtsh Frauenheilk 2010; 70: 85-100

4 Müller A, Keller K, Wacker J et al. Retransplantation von kryokonserviertem Ovarialgewebe: Erste Geburt in Deutschland. Dtsch Arztebl Int 2012; 109: 8-13

5 Mueller A, Oppelt PG, Renner SP et al. Erste Retransplantation von kryokonserviertem Ovarialgevebe nach Krebserkrankung in Deutschland mit anschließender Eizellgewinnung und ICSI-Behandlung. Geburtsh Frauenheilk 2009; 69: 124-130

6 Isachenko V, Isachenko E, Nawroth F et al. Genexpression und Morphologie der Follikel nach konventionellem Einfrieren und Vitrifikation von humanem Ovarialgewebe. Geburtsh Frauenheilk 2010; 70: 561567

7 Isachenko $\mathrm{V}$, Montag $M$, Isachenko $\mathrm{E}$ et al. Effective method for in-vitro culture of cryopreserved human ovarian tissue. Reprod Biomed Online 2006; 13: 228-234

8 Isachenko V, Nawroth F, Rahimi G et al. Die vaskularisierte Chorioallantoismembran (CAM): Ein Kultursystem für kryokonserviertes menschliches Ovarialgewebe als Alternative zur Xenotransplantation. Geburtsh Frauenheilk 2011; 71: 862-868

9 Isachenko V, Isachenko E, Rahimi G et al. Die Chorioallantoismembran des Huhns. Kultursystem für kryokonserviertes menschliches Ovarialgewebe. Gynäkol Endokrinol 2012; 10: 65-67

10 Isachenko V, Mallmann P, Petrunkina AM et al. Comparison of in vitroand chorioallantoic membrane (CAM)-culture systems for cryopreserved medulla-contained human ovarian tissue. PLoS ONE 2012; 7: e32549

11 Fiedler J, Jara P, Luza S et al. Cold stress induces metabolic activation of thyrotrophin-releasing hormone-synthesising neurones in the magnocellular division of the hypothalamic paraventricular nucleus and concomitantly changes ovarian sympathetic activity parameters. J Neuroendocrinol 2006; 18: 367-376

12 Isachenko V, Ostashko F, Grishchenko V et al. Survival of trophoblastic fragments and vesicles after vitrification, ultrarapid freezing, and storage at 4 degrees C. Cryobiology 1993; 30: 432-437

13 Isachenko $E$, Isachenko $V$, Nawroth $F$ et al. Effect of long-term exposure at suprazero temperatures on activity and viability of human ovarian cortex. Fertil Steril 2009; 91: 1556-1559 
14 Wood TW, Montali RJ, Wildt DE. Follicle-oocyte atresia and temporal taphonomy in cold-stored domestic cat ovaries. Mol Reprod Dev 1997; 46: 190-200

15 Yin H, Wang X, Kim SS et al. Transplantation of intact rat gonads using vascular anastomosis: effects of cryopreservation, ischemia and genotype. Hum Reprod 2003; 18: 1165-1172

16 Weissman A, Gotlieb L, Colgan T et al. Preliminary experience with subcutaneous human ovarian cortex transplantation in the NOD-SCID mouse. Biol Reprod 1999; 6: 1462-1467

17 Carmeliet P. Angiogenesis in health and disease. Nat Med 2003; 9: 653660

18 Khan-Dawood FS, Yusoff Dawood M, Tabibzadeh S. Immunohistochemical analysis of the microanatomy of primate ovary. Biol Reprod 1996; 54: 734-742
19 Isachenko V, Mallmann P, Isachenko E et al. Long-time cooling of human ovarian tissue before cryopreservation as obvious procedure: stimulation of follicular development and neo-vascularisation. Clin Lab 2013; in press

20 Dittrich R, Lotz L, Keck $G$ et al. Live birth after ovarian tissue autotransplantation following overnight transportation before cryopreservation. Fertil Steril 2012; 97: 387-390

21 Donnez J, Jadoul P, Pirard C et al. Live birth after transplantation of frozen-thawed ovarian tissue after bilateral oophorectomy for benign disease. Fertil Steril 2012; 98: 720-725

Deutschsprachige Zusatzinformationen online abrufbar unter: www.thieme-connect.de/ejournals/toc/gebfra. 